This item was submitted to Loughborough's Research Repository by the author.

Items in Figshare are protected by copyright, with all rights reserved, unless otherwise indicated.

\title{
Theoretical perspectives in purchasing and supply chain management: an analysis of the literature
}

PLEASE CITE THE PUBLISHED VERSION

http://dx.doi.org/10.1108/13598541211246611

PUBLISHER

(C) Emerald

VERSION

AM (Accepted Manuscript)

\section{PUBLISHER STATEMENT}

This work is made available according to the conditions of the Creative Commons Attribution-NonCommercialNoDerivatives 4.0 International (CC BY-NC-ND 4.0) licence. Full details of this licence are available at: https://creativecommons.org/licenses/by-nc-nd/4.0/

\section{LICENCE}

CC BY-NC-ND 4.0

\section{REPOSITORY RECORD}

Chicksand, Daniel, Robert Johnston, Glyn Watson, Helen Walker, and Zoe J. Radnor. 2019. "Theoretical Perspectives in Purchasing and Supply Chain Management: An Analysis of the Literature". figshare. https://hdl.handle.net/2134/15863. 


\title{
Theoretical perspectives in purchasing and supply chain management: an analysis of the literature
}

\begin{abstract}
The research presented in this paper aims to build on the recent work of Defee et al. (2010) that attempted to examine the use of theory in the logistics discipline. As part of their findings, Defee et al. found that more than half of all articles published in the discipline's leading journals made use of theory, with much of this theory drawing on the work of microeconomists. The paper seeks to determine whether the same is true of P\&SCM more generally. To the extent that theory is now being used, it also seeks to determine what this means for the field. In her work into the development of Business Management as a discipline, Frances Fabian (2000) argued that disciplines can be categorised according to three criteria: coherence, breadth and depth of knowledge, and quality. In order to be considered scientific, Fabian argued that a discipline needed to be theoretically coherent and to have adopted common (positivist) standards for assessing the relative contribution of new work (breadth/depth of knowledge and quality). Judged by the standards adopted in this paper, it is argued that P\&SCM is some way off becoming a scientific discipline of the type exemplified by physics or one of the other natural sciences.
\end{abstract}

Key words: purchasing and supply chain management, theory, literature review

\section{Introduction}

Purchasing and supply chain management (P\&SCM) started to develop as an area of significant academic enquiry in the early 1990s. The focus of enquiry and subject matter in this field is extremely diverse and continues to broaden. Key topics of research interest include the following: contractual relationships, data interchange and vertical integration, efficient consumer response, investment in emerging economies, just in time, logistics, organisational behaviour and risk management ${ }^{1}$. This paper presents an analysis of the rise of the P\&SCM field and concludes that the discipline, while being an increasingly rich one, should not be considered as scientific because there are some significant deficiencies in terms of its coherence, breadth and depth, and quality, according to Fabian's (2000) three tests of what makes an academic discipline. Indeed, the authors would further argue that the broadening of the discipline's research agenda may even have limited the sorts of cumulative

\footnotetext{
${ }^{1}$ Supply Chain Management: An International Journal lists the key topics as: contractual relationships; data interchange and vertical integration; efficient consumer response; investment in emerging economies; just in time; logistics; organizational behaviour; and risk management. The Journal of Purchasing and Supply Management lists the key topics as: purchasing and supply in a strategic context; organisational buying behaviour; make-or-buy/outsourcing strategy; global/international sourcing; supplier relationships; tendering and contracting; costing and pricing; negotiation; purchasing and supply organisation; information management and information \& communication technology (ICT); social, ethical and environmental supply issues; supply chain management; and public procurement.
} 
knowledge building that one normally associates with scientific enquiry - at least in the short term.

Many of the topics most central to researchers working in the field of P\&SCM, such as relationship management, contractual relationships, just in time (JIT), organisational behaviour and social, ethical and environmental supply issues, have developed their own agenda's and sub-disciplinary debates. The result of this is that researchers working in the area now make use of a diverse range of theories. In addition to such home-grown approaches such as integrated supply chain management (ISCM), researchers also make use of a number of other theories including: principal agent theory (PAT) and transaction cost economics (TCE) from economics; resource based view (RBV), the dynamic capabilities approach (DCA) and industrial organisational theory (IO) from business strategy; resource dependence theory (RDT) from economic sociology; as well as industrial marketing and purchasing (IMP) / network theory (NT) from business management.

In a recent paper on the use of theory in logistics and SCM research, Defee, Brent, Williams, Randall and Thomas welcomed this development on the basis that good research is grounded in theory (Defee, et al., 2010). Indeed they argued that the use and development of theory is necessary if a discipline is to move beyond the pre-paradigmatic phase (p.404). Their main concern seemed to be that there was still further scope to make use of theory within the logistics field (p.420). The authors of this paper would endorse this position, but with the caveat that while the use of theory is a necessary condition for the maturation of a discipline, it is not a sufficient one. Some authors argue that intellectual pluralism is a sign of a healthy discipline (Feyerabend, 1975) and viewing a discipline through multiple lenses, conceptual frameworks or theories creates valuable insights (Shook et al., 2009). In addition, Halldorsson et al., (2007) contend that there is no 'right' theory for understanding the management of integrated supply chains. However, it can also be argued that disciplinary development, at least if it is to occur along scientific lines, requires that at some point researchers working in the area develop a common understanding of some of the key concepts and most profitable lines of enquiry (Amundson, 1998). In their findings, Defee et al. (2010) seemed to suggest that this was the case, at least for the field of logistics. In their survey, they found that not only was theory used in over half of the sampled articles that they looked at, but that where it was used, microeconomic and competitive approaches made up over forty per cent of the contributions.

These findings contrast sharply with the work of Harland et al. (2006) which attempted to look at the development of supply management more generally as a discipline (2006). Like Defee et al. Harland et al. took as their starting point the idea that theory was important to the development of a discipline. However, they shared with Pfeffer certain reservations about the indiscriminate use of theory. Pfeffer (1982) famously argued that the proliferation of theory within a discipline leads to a discipline that resembles 'more of a weed patch than a well tended garden' (Pfeffer, 1993, p. 616). Competition between ideas is only to be welcomed if at some point the areas of dispute are resolved. Drawing on the work of Fabian (2000), they argued that in order for it to be considered a discipline, supply management 
needed to pass three tests: coherence, quality and breadth and depth. To these they added a fourth element: the existence of discipline-debate on the key issues. Of these measures, coherence played a central role. In a pre-disciplinary phase, they argued that a field tended to be characterised by a broad range of themes, an inconsistent use of terms and the disjointed use of previous work (p.736). They concluded that while there was some evidence of increasing coherence and quality (particularly in terms of the research focus and impact of some of the research), there was little evidence of a discipline-debate. As such, they concluded that supply management was too immature to be characterised as a discipline - at least in the scientific sense.

In this paper the authors have attempted to seek answers to three questions. Two of these questions have been borrowed (but adapted) from the work of Defee et al. (2010):

RQ1. To what extent is theory used in P\&SCM research?

RQ2. What are the prevalent theories to be found in P\&SCM research?

Following on from these two questions, and drawing on the work of Harland et al. (2006), the authors have added a third question:

RQ3. To what extent does P\&SCM meet the tests of coherence, breadth and depth, and quality necessary to make it a scientific discipline?

In attempting to answer these questions, this study has built on the existing literature in a number of ways. Firstly, it extends the work of Defee et al. (2010), by looking at the use of theory in the field of $\mathrm{P} \& S C \mathrm{~S}^{2}$. It will be interesting to see whether or not what is true of the logistics field specifically is also true of P\&SCM more generally. P\&SCM is larger in scope, and the work of Harland et al. (2006) would suggest that there may be notable differences. Secondly, it updates the work of Harland et al. (2006). Finally, this study adds breadth to the data. In arriving at the results presented in this paper, 1113 articles were surveyed from three of the key journals in the P\&SCM field over a thirteen year period.

\section{A review of the scientific development of disciplines}

As Defee et al.(2010) point out in their work, over the last decade a number of papers have been dedicated to mapping and assessing the fields of purchasing, logistics and SCM. Defee et al. (2010) cite the contributions of Miyazaki et al. (1999), Giunipero et al. (2008), Stock (2001), Stock and Broados (2006), Stock and Luhsen (1993), Selviaridis and Spring (2007) and Williams and Tokar (2008). To these could be added the work of Harland et al. (2006), Burgess et al., (2006) and now Defee et al. (2010) themselves. In the case of Defee et al.

\footnotetext{
${ }^{2}$ Defee et al's (2010) findings were drawn from five of the leading logistics journals: the JBL, Transportation Journal, the Journal of Supply Chain Management, the International Journal of Physical Distribution \& Logistics Management, and the International Journal of Logistics Management.
} 
(2010) one of the distinctive contributions that they make is in emphasising the central role of theory in the development of a discipline.

In their work, Defee et al. (2010) use Hunt's (1991) definition of theory as a 'systematized structure capable of explaining and predicting phenomena' (Defee et al., 2010, p.406). However, within the natural sciences such a definition requires qualification. In addition to its ability to explain and predict empirical phenomena, theory is developed in ways that are consistent with scientific method. This involves hypothesis development and testing and requires that any researcher working in the field is able to understand what is being said, and replicate (or refute) the results. Central to the notion of a scientific discipline is the idea that the frontiers of knowledge expand cumulatively (Amundson, 1998). While mature scientific disciplines require the use of theory, not all disciplines that use theory are scientific. Drawing on the work of Frances Fabian (2000), this was essentially the point that was made by Harland et al (2006).

In her now classic article Fabian attempted both to develop a typology of academic disciplines and locate business management within it. For the first part of this exercise, Fabian identified three criteria that could be used to categorise an academic discipline. These were (a) coherence, (b) breadth and depth, and (c) quality.

On the subject of coherence, Fabian distinguishes between unified disciplines (i.e. disciplines with a single paradigm), segregated disciplines (i.e. disciplines with no paradigms), and integrated disciplines (i.e. disciplines that tolerate plurality but which seek some sort of accommodation between the different parties). For Fabian, a unified discipline is one where researchers shared a common understanding of the world that they seek to describe (what might be called a paradigm by Thomas Kuhn) (Kuhn, 1970). Often disciplines that exhibit high degrees of solidarity are resistant to the emergence of new ways of looking at key problems, particularly where they challenge the prevailing orthodoxy. By contrast, a segregated discipline shows no evidence of an overarching theory or common approach to the key disciplinary problems. It is a state somewhat akin to the wild west where 'anything goes' (Fabain, 2000, p.358). According to Fabian it represents the kind of extreme relativism advocated by Feyerabend (1975), where all approaches are regarded as being potentially legitimate. Unsurprisingly, integrated disciplines sit somewhere between the two extremes. Disciplines characterised by integration are open to new ideas, but desire the new entrants to fit in. The main debate to be found within integrated disciplines is how this might be accomplished. One strategy is to accept that some theories explain some things better than others, and to select a theory on the basis that it is the best fit for the problem at hand. The second approach is to build bridges so that, over time, all sides come to resemble each other somewhat (i.e. over time the discipline moves to a more integrated state). The degree to which this is likely to happen will, of course, depend upon the theoretical commensurability of the different approaches.

According to Fabian's second criterion, a discipline can also be categorised on the basis of its breadth, or epistemological stance. Is the priority of the discipline to preserve the current 
epistemological stance and use it to deepen the disciplines understanding of key problems? Or, does the discipline demonstrate a willingness to extend the kinds of knowledge that are used, in order to open up new areas of enquiry (p.353). It is commonplace when discussing method to distinguish between induction (or empiricism) and deduction (philosophical enquiry). The former relies on observation for the development of theory; the latter on logical inference (usually operating from first principles) (Stoker, 1995; Saunders et al., 2007). Much of the historic development of social sciences like sociology rests upon induction. By contrast, neo-classical economics remains to this day, a largely deductive subject. Modern scientific method, often taken to be the gold standard of disciplinary enquiry, represents a fusion of induction and deduction (Richy et al., 2010). According to the hypothetico-deductive process, progress in a discipline is achieved through: the development of clear testable (i.e. falsifiable) hypothesis; the testing of these hypotheses; the endorsement, refinement or rejection of hypotheses based upon the findings in the data; and, the subsequent development of clear concepts and theories (Hollis, 1997, pp. 38-44).

Finally, a discipline can be categorised on the basis that it reviews and evaluates new and existing contributions (what Fabian refers to as quality). At one extreme, disciplines can adopt a universal standard for peer reviewing work. Examples of this are to be found in the natural sciences where the use of advanced statistical techniques is the norm; or economics, where theoretical elegance and mathematical precision are the principle ways in which new contributions are judged.

Fabian uses these three measures (coherence, breadth-depth and quality) to generate a typology of disciplinary states. She identifies twelve possible states, but describes only nine. These range from Disconfirmation (or single/dominant paradigm disciplines, where there are common standards for undertaking research and reviewing work), to Restructuring (where disciplines operate an open-door policy, and which will periodically restructure themselves when something particularly useful comes along). Between these extremes are a number of middle types where a discipline is happy to tolerate diversity but seeks some accommodation. Fabian herself makes no detailed judgement about the respective merits of different sorts of discipline, although she does allude to some of the benefits of intellectual tension and periodic disciplinary introspection.

In terms of developing as a scientific discipline, the authors of this paper wound agree with Amundson (1998) that the epistemological approaches adopted by researchers can be critical. Positivists, for example, are almost always defined by a shared belief that new contributions to knowledge should be amenable to verification (i.e. that they should be falsifiable) and have a shared optimism that it is possible to derive causation for a better understanding of the world. By contrast, Constructivists are sceptical about the very idea of intellectual progress. They believe that the world is socially constructed and does not exist independent of the participant-observer. Because of this they are more likely to be advocates of the sort of pluralism that is likely to leave a discipline in a state of theoretical limbo (see for example, Gallie, 1955-6; Connolly, 1972; Lukes, 1974 and 1986; and McLennan, 1989). The implication of this is clear. Ceteris paribus, disciplines that do not make use of scientific 
method (or at least are not able to agree on some other method for assessing theoretical merit), remain cluttered with competitors and are less likely to pass Fabian's test of coherence. Likewise, quality plays a pivotal role since, for Fabian, quality is about the development of accepted norms for evaluating contributions (e.g. the use of various types of case method as opposed to advanced statistical techniques). Without agreement about the quality of evidence it may be difficult to find agreement over the contribution of a piece of research. This, in turn, makes it more difficult to sort the more valuable from the less valuable.

In sum, therefore, in terms of providing answers to the questions that we posed at the start of the paper, the authors would suggest the following. Firstly, and most obviously, we are looking to see to what extent the use of theory has become integral to the study of P\&SCM. Defee et al. (2010) have suggested that the use of theory in the discipline of logistics is now extensive. Is this also true of P\&SCM? Five years ago, Harland et al. (2006) suggested that theory does not play an important part. Secondly, to the extent that the discipline may now have changed (and theory is being used extensively), has the discipline developed a common way of thinking about problems (i.e. is there theoretical unity?)? That is to say (a) has the discipline developed a robust and rich theoretical base; and (b) to the extent that such a base exists, are their signs of growing agreement amongst researchers about which are the most useful perspectives. Defee et al. (2010) showed that in the case of logistics there were signs that competitive and microeconomic approaches might be emerging as the dominant way of looking at problems. Is the same also true of P\&SCM? If there is little theory to be found in P\&SCM, then this would suggest that P\&SCM is still in its infancy. If, however, there are clear signs of theoretical development, the question then becomes, to what extent is there agreement amongst researchers about which perspectives are the most useful. If a single dominant paradigm has started to emerge, then this would indicate that P\&SCM has progressed to the status of a normal science. However, if P\&SCM exhibits multiple perspectives, then this would indicate that the discipline is currently segregated. This then raises the question of whether or not the discipline is likely to integrate. The answer to this question rests on tests two and three. These are: (a) the level of agreement amongst researchers regarding the appropriate epistemological approach to take to the research (e.g. positivist vs. constructivist); and (b) the levels of agreement regarding the appropriate way to measure the quality of new contributions (e.g. the balance of theory to practice, the use of case versus statistical evidence etc.). If norms relating to the conduct of research are starting to emerge, then this suggests that the discipline has the potential to integrate the various contributions, even if this has not yet happened.

\section{Methodological approach to literature review}

According to Tranfield et al. (2003) a systematic literature review requires the adherence to a series of techniques with the aim of 'minimising bias and error' (p. 210). Creating a transparent and auditable trail of the 'reviewers' decisions, procedures and conclusions' ( $\mathrm{p}$. 209) leads to 'high quality evidence' (p. 210). When designing this systematic literature 
review, in accordance with the model outlined by Tranfield et al. (2003) (and discussed in more detail by Rosseau et al., 2008 and Denyer and Tranfield, 2009) a number of stages were followed.

In the planning review stage a review panel of five academics from three UK business schools was formed. The aim was to identify a need for the review, prepare a proposal and develop a review protocol (Tranfield et al., 2003 p. 214). The second stage was to conduct the review. A scoping exercise was conducted to fully define the scope of the study, the data to be collected and the data collection process. Three journals were chosen in the field of 'purchasing and supply chain management' as identified in the Association of Business Schools journal list (Harvey, Morris, and Kelly, 2009) to find evidence to answer the research questions. These were: Supply Chain Management: an International Journal (SCMIJ); the Journal of Purchasing and Supply Management (JPSM) (formerly the European Journal of Purchasing and Supply Management); and, the Journal of Supply Chain Management (JSCM). It is acknowledged that other journals such as the Journal of Logistics Management, the British Journal of Management and the International Journal of Operations and Production Management, to name just a few, also featured articles in the field of 'purchasing and supply chain management'. However, the review panel chose the three journals because: (a) as the titles of the journals suggest, their focus was primarily upon P\&SCM key topics, whereas other journals drew more heavily on alternative topics, such as operations management, productions management and strategy etc.; (b) a key word search for the term 'purchasing and supply chain management' identified a high number of relevant articles in these journals; (c) after consultation with academics at other leading worldwide business schools the three journals were considered to be the most representative of the field; (d) previous research (see Harland et al., 2006; Halldorsson et al., 2003; Miri-Lavassani, et al., 2009 and Defee et al., 2010) based their research on filtering the data sample through key word searches based primarily on logistics, purchasing and supply chain management. However, this considerably narrows the scope of the study. As has been expressed previously within P\&SCM there is a multiplicity of key topics such as relationship management, contractual relationships, just in time (JIT), organisational behaviour and social, ethical and environmental supply issues, to name but a few. By not limiting the search to a small number of key words this paper can capture the true diversity of the subject. It may be the fact that theory only lends itself to enquiry into certain phenomenon such as relationships, for example; and, (e) as papers from every journal volume and issue from 1994 onwards would be reviewed, for practical reasons, it was deemed that it would only be possible to complete three full journal reviews.

Although the JSCM commenced in 1965 the decision was made to review all articles from 1994 onwards as the JPSM and SCMIJ commenced in 1994 and 1996 respectively. It was felt that the time frame (16 years) was sufficient and would provide a large data set (1113 articles). Furthermore, covering the same period for the three journals limits the influence on the findings of the specific editorial policies (such as a preference for qualitative or quantitative research) of one of the journals. In addition, it would be possible to conduct 
potentially interesting inter-journal analyses over the period. Of the 1113 articles analysed, 331 were from JSCM, 477 from JPSM and 329 were from SCMIJ.

Particular attention was made to the coding of each of the 1113 analysed articles. The process of coding the papers will now be described in full. First, key data groups were identified from the scoping study, a review of the literature and in-depth discussions by the review panel. As highlighted in Table 1, the aim was to collect rich data for each paper. The first four data groups are for identification purposes (the first four columns in Table 1) and several other data groups will help with further analysis, which is outside of the scope of this study (such as topic, country, sector, etc.). To ensure consistency and repeatability each data set was clearly specified and categorised. This was particularly important for a number of key fields including: the type of paper (see Table 2 below), method of data collection and dominant theory (see Table 3 below). It was these fields, in particular, which if not clearly specified could potentially cause the greatest inconsistency and impact on the study.

\section{Table 1: Key Data Groups}

\begin{tabular}{|c|c|c|c|c|c|c|c|c|c|c|c|c|c|c|c|}
\hline $\begin{array}{l}\text { Lead } \\
\text { Author } \\
\text { Initials }\end{array}$ & Year & Volume & Issue & $\begin{array}{l}\text { Type of } \\
\text { paper }\end{array}$ & $\begin{array}{l}\text { Method of } \\
\text { data } \\
\text { collection }\end{array}$ & $\begin{array}{c}\text { Topic - First } \\
\text { keyword if } \\
\text { posshle }\end{array}$ & $\begin{array}{c}\text { Lit } \\
\text { review } \\
\text { length in } \\
\text { pgss }\end{array}$ & $\begin{array}{l}\text { Reference } \\
\text { list length } \\
\text { inpgs }\end{array}$ & $\begin{array}{l}\text { Concept } \\
\text { model } \\
\text { framework }\end{array}$ & $\begin{array}{l}\text { Dominant } \\
\text { theory }\end{array}$ & $\begin{array}{l}\text { If 'other', } \\
\text { what } \\
\text { theory? }\end{array}$ & Country & $\begin{array}{l}\text { Sector e.g. } \\
\text { Automotive } \\
\text { etc }\end{array}$ & $\begin{array}{l}\text { Public/ } \\
\text { Private }\end{array}$ & $\begin{array}{l}\text { Useful } \\
\text { quotes / } \\
\text { notes }\end{array}$ \\
\hline JB & 1994 & 1 & 1 & $\begin{array}{c}1 . \\
\text { Conceptual }\end{array}$ & 4. None & $\begin{array}{c}\text { TQM, } \\
\text { Relationships }\end{array}$ & $\begin{array}{l}5.2+ \\
\text { pages }\end{array}$ & $\begin{array}{c}4.1 \text { to } 2 \\
\text { pages }\end{array}$ & 1.Yes & 15. None & & 259. None & 38. None & 4. None & $\begin{array}{l}\text { Lots of info } \\
\text { about } \\
\text { relationshipe }\end{array}$ \\
\hline $\mathrm{DM}$ & 1994 & 1 & 1 & $\begin{array}{c}1 . \\
\text { Conceptual }\end{array}$ & 4. None & $\begin{array}{l}\text { Purchasing, } \\
\text { Partnering }\end{array}$ & $\begin{array}{c}2.0-1 / 2 \\
\text { pages }\end{array}$ & $\begin{array}{c}2.0-1 / 2 \\
\text { pages }\end{array}$ & 2. No & 15. None & & 259. None & 38. None & 4. None & $\begin{array}{c}\text { Introduces } \\
\text { adversarial } \\
\text { V's } \\
\text { collaborative } \\
\text { relationship }\end{array}$ \\
\hline$L G$ & 1994 & 1 & 1 & $\begin{array}{c}7 . \\
\text { Positional }\end{array}$ & 4. None & $\begin{array}{l}\text { Purchasing, } \\
\text { Strategy }\end{array}$ & $\begin{array}{l}5.2+ \\
\text { pages }\end{array}$ & $\begin{array}{c}3.1 / 2 \text { to } 1 \\
\text { pages }\end{array}$ & 2. No & 15. None & & $\begin{array}{l}\text { 1. Multiple } \\
\text { country }\end{array}$ & $\begin{array}{c}6 . \\
\text { Automotive }\end{array}$ & 2. Private & $\begin{array}{l}\text { mentions } \\
\text { other sectors }\end{array}$ \\
\hline $\mathrm{PF}$ & 1994 & 1 & 1 & 4. Survey & $\begin{array}{c}2 . \\
\text { Qualitative }\end{array}$ & $\begin{array}{l}\text { Competition, } \\
\text { partnership }\end{array}$ & $\begin{array}{c}2.0-1 / 2 \\
\text { pages }\end{array}$ & $\begin{array}{c}2.0-1 / 2 \\
\text { pages }\end{array}$ & 1. Yes & 15. None & & $\begin{array}{l}\text { 2. United } \\
\text { Kingdom }\end{array}$ & $\begin{array}{l}\text { 1. Multiple } \\
\text { sector }\end{array}$ & 3. Mixed & \\
\hline $\mathrm{JG}$ & 1994 & 1 & 1 & $\begin{array}{l}\text { 6. Case } \\
\text { Study }\end{array}$ & $\begin{array}{c}2 . \\
\text { Qualitative }\end{array}$ & Outsourcing & 1.0 pages & 1.0 pages & 2. No & 15. None & & $\begin{array}{l}\text { 2. United } \\
\text { Kingdom }\end{array}$ & $\begin{array}{l}\text { 8. Business } \\
\text { ( } \& \\
\text { Consumer) } \\
\text { Services }\end{array}$ & 2. Private & \\
\hline
\end{tabular}




\section{Table 2: Type of article with detailed description}

\begin{tabular}{|l|l|l|}
\hline Coding & $\begin{array}{l}\text { Type of } \\
\text { Article }\end{array}$ & Description of Type of Article \\
\hline $1=$ & Conceptual & $\begin{array}{l}\text { i.e. an article which primary discusses / contributes towards theory } \\
\text { building }\end{array}$ \\
\hline $2=$ & Lit Review & i.e. primary focus of article is to review current literature in field \\
\hline $3=$ & Simulations & $\begin{array}{l}\text { i.e. primary concerned with mathematical modelling of a problem- } \\
\text { could also be seen as modelling }\end{array}$ \\
\hline $5=$ & Survey & i.e. primarily concerned with reporting back on a survey \\
\hline $6=$ & Case Study & $\begin{array}{l}\text { i.e. either mathematical or focused on solving on technical problem } \\
\text { e.g. forecasting for lead pipes }\end{array}$ \\
\hline $7=$ & Positional & $\begin{array}{l}\text { i.e. giving a view or position on something drawing from some } \\
\text { empirical data and/or literature but not grounded in it e.g. Terry } \\
\text { Hills view of manufacturing strategy }\end{array}$ \\
\hline
\end{tabular}

* If a mix of the above, choose one of the above as the main type

The 'dominant theory' field required careful consideration. There is considerable academic discourse as to what constitutes a theory (Fabian, 2000) and what makes a 'good' theory (Wacker, 1998). Furthermore, there is no consensus as to which theories should be applied to explain particular problems or issues arising within the purchasing and supply chain management discipline. However, it is not within the remit of this paper to directly enter into this debate (for more information see the article by John Wacker, 1998). What was clear from the initial review of the literature and discussions by the review panel was that there were different theoretical 'lenses' or perspectives used to generate knowledge in the field of P\&SCM. Although a young discipline, P\&SCM is also a relatively rich one. Shook et al. (2009) viewed strategic sourcing from ten theoretical perspectives: institutional theory; systems theory; resource/knowledge based views of the firm (RBV); transaction cost economics (TCE); principal agency theory (PAT); strategic choice theory; sociocognitive theory; and, critical theory (p. 3). Halldorsson et al. (2007) drew from principal-agency theory, transaction costs analysis, the resource-based view and the network perspective (IMP/NT) and applied these theoretical frameworks to third party logistics and new product development.

The panel was, therefore, able to provide a coding for the potential theories from which it was felt that the field of P\&SCM would likely draw from (see Table 3). 
Table 3: Dominant Theory

\begin{tabular}{|c|l|l|}
\hline $\mathbf{1}=$ & Transaction Cost Economics (TCE) \\
\hline $\mathbf{2}=$ & Goal Systems Theory (GST) \\
$\mathbf{3}=$ & Equity Theory (ET) \\
\hline $\mathbf{4}=$ & Resource Dependency Theory (RDT) \\
\hline $\mathbf{5}=$ & Game Theory (GT) \\
\hline $\mathbf{6}=$ & Theory of Constraints (TOC) \\
\hline $\mathbf{7}=$ & Systems Theory (ST) \\
\hline $\mathbf{8}=$ & Two Factor Theory (TFT- extension to RBV) \\
\hline $\mathbf{9}=$ & Industrial Organisational Theory (IO) \\
\hline $\mathbf{1 0}=$ & Resource Based View (RBV) $/$ Dynamic Capabilities Approach (DCA) \\
\hline $\mathbf{1 1}=$ & Contingency Theory (CT) \\
\hline $\mathbf{1 2}=$ & Principal Agency Theory (PAT) \\
\hline $\mathbf{1 3}=$ & Property Rights Theory (PRT) \\
\hline $\mathbf{1 4}=$ & Other- put other theories in next column \\
\hline $\mathbf{1 5}=$ & No Distinctive Intellectual Tradition (NDIT) \\
\hline $\mathbf{1 6}=$ & Integrated Supply Chain Management (ISCM) \\
\hline $\mathbf{1 7}=$ & Intellectually Eclectic (IE) \\
\hline
\end{tabular}

During the discussion by the review panel, after the scoping exercise and review of the literature had been completed, an 'other' theory categorisation was included to ensure that the coding was flexible enough to allow for other categories to emerge during the research. It was also felt that a number of articles sought to marry different theoretical approaches. For example, the literature review identified articles that attempted to fuse the resource based view (RBV) / dynamic capabilities approach (DCA) from mainstream business strategy, and transaction cost economics (TCE) / principal agency theory (PAT) from mainstream and new institutional economics. These articles would be captured in the 'intellectually eclectic' (IE) categorisation. The 'no distinctive intellectual tradition' (NDIT) category would capture articles which did not clearly draw upon theory to explain or investigate a phenomenon.

To assist the researchers in the process of codification, a number of the key theories are organised (albeit sometimes distantly) into related families and summarised in Table 4 below. In compiling this table a distinction was made between the theory having a focus on either efficiency or power. Integrated supply chain management (ISCM) School had as its chief focus inter-organisational cooperation for the purpose of enhancing customer satisfaction and operational efficiency. With industrial marketing and purchasing (IMP) / network theory (NT) the chief focus is also on building trust and cooperation to improve operational efficiency. Transaction cost economics (TCE) and principal agency theory (PAT) share with ISCM and IMP/NT, efficiency as their main intellectual preoccupation. However, while 
ISCM looked at the operational steps required to produce the efficient throughput of product (what Williamson has called fourth-order economising), and IMP/NT looked at the choice of network partners (those that are central to a network) to deliver the efficient throughput of product, both TCE and PAT were interested in efficiency as an incentive problem. Like ISCM, TCE and PAT, industrial organisational theory (IO), RBV, DCA and resource dependency theory (RDT) also share a common interest. In the case of these four approaches, however, their interest is in power (a concept whose relevance is explicitly placed at the margins of legitimate enquiry by TCE) (Williamson, 1995). However, there are important differences between the four 'power' approaches. The related approaches of the RBV and the DCA are interested in the relationship between power and competitiveness. IO and RDT, by contrast, are more interested in the relationship between power and surplus value. However, IO and RDT draw very different conclusions regarding the normative value of market power. While RDT concerns itself with the relative costs and benefits to exchange partners, IO ranges more widely in that it also considers the welfare implications to third parties. The key point is that while on the surface some of the approaches may look similar or different but complementary, they are in fact analytically distinct. This means that they cannot be combined together indiscriminately causing the problems of commensurability that has already been discussed.

Table 4: Key theories / approaches within the discipline

\begin{tabular}{|c|c|c|}
\hline Theory & Focus & Description \\
\hline $\begin{array}{l}\text { Integrated Supply } \\
\text { Chain } \\
\text { Management } \\
\text { (ISCM) }\end{array}$ & Efficiency & $\begin{array}{l}\text { Inter-organisational cooperation for the purpose of enhanced customer satisfaction and operational efficiency. } \\
\text { Looked at the operational steps required to produce the efficient throughput of product (e.g. Cusumano, 1984; } \\
\text { Womack et al., 1990; Ellram, 1990; Macbeth and Ferguson, 1994; Lamming, 1993, 1996; Womack and Jones, } \\
\text { 2005) }\end{array}$ \\
\hline $\begin{array}{l}\text { Industrial } \\
\text { Marketing and } \\
\text { Purchasing (TMP) } \\
\text { / Network Theory } \\
\text { (NT) }\end{array}$ & Efficiency & $\begin{array}{l}\text { Interested in how the relationships a firm has with other firms influence behaviour and outcomes. The central } \\
\text { premise is that managing inter-organisational relationships is key to success. A firm's centrality to a network is } \\
\text { an important driver and enhances the firm's competitive priorities in a supply chain. The choice of partners } \\
\text { drives operational efficiency (e.g. Ford, 1980; Thorelli, 1986; Haakansson and Snehota, 1995; Gulati et al., } \\
\text { 2000; Haakansson and Ford, 2002) }\end{array}$ \\
\hline $\begin{array}{l}\text { Transaction Cost } \\
\text { Economics (TCE) }\end{array}$ & Efficiency & $\begin{array}{l}\text { Efficiency as an incentive problem. Hold-up is the principal focus of TCE. Safeguards are centred on } \\
\text { governance (e.g. Alchian and Woodwood, 1988; Coase, 1937; and Williamson, 1985, } 1991 \text { and 2000) }\end{array}$ \\
\hline $\begin{array}{l}\text { Principal Agency } \\
\text { Theory (PAT) }\end{array}$ & Efficiency & $\begin{array}{l}\text { Efficiency as an incentive problem. Adverse selection and moral hazard are the efficiency problems analysed by } \\
\text { PAT. Safeguards are centred on the contract (e.g. Eggertsson, 1990; Hart, 1989; Milgrom and Roberts, 1992) }\end{array}$ \\
\hline $\begin{array}{l}\text { Industrial } \\
\text { Organization (IO) }\end{array}$ & Power & $\begin{array}{l}\text { Interested in the relationship between power and surplus value, but also considers the welfare implications to } \\
\text { third parties. The differences between the relative dependence of contracting parties, confers commercial } \\
\text { advantage of the dominant actor. However, this is not to be welcome. Discussion of power implicit. (e.g. Porter, } \\
1979,1991 \text { and 1981; Demsetz, 1973; and Rumelt et al., 1991) }\end{array}$ \\
\hline $\begin{array}{l}\text { Resource Based } \\
\text { View (RBV) }\end{array}$ & Power & $\begin{array}{l}\text { Interested in the relationship between power and competitiveness. Power differentials provide the basis for a } \\
\text { firm's strategy. However, these advantages originate not in the transaction but in the internal processes of the } \\
\text { firm. Discussion of power implicit (e.g. Barney, 1991; Conner and Prahalad 1996; Peteraf, 1993) }\end{array}$ \\
\hline $\begin{array}{l}\text { Dynamic } \\
\text { Capabilities } \\
\text { Approach (DCA) }\end{array}$ & Power & $\begin{array}{l}\text { Interested in the relationship between power and competitiveness. However, these advantages originate not in } \\
\text { the transaction but in the internal processes of the firm. Discussion of power implicit (e.g. Foss, } 2005 \text { and Teece } \\
\text { et al., 1997) }\end{array}$ \\
\hline $\begin{array}{l}\text { Resource } \\
\text { Dependency } \\
\text { Theory (RDT) }\end{array}$ & Power & $\begin{array}{l}\text { Interested in the relationship between power and surplus value. Similar to TCE in that it puts the transaction (or } \\
\text { exchange process), at the centre of its analysis. It holds that differences between the relative dependence of } \\
\text { contracting parties, confers commercial advantage of the dominant actor. Unlike IO this is welcome and forms } \\
\text { basis of its competitive advantage. Discussion of power explicit (e.g. Emerson, 1962; Salancik, G. and Pfeffer, } \\
\text { J., 1977; Ramsay, J. 1996; Cox et al., 2000). }\end{array}$ \\
\hline
\end{tabular}


Having justified the key data groups and the coding of the articles the process of coding the papers will now be discussed. The data collection process had a number of stages:

1) Three researchers coded the papers independently (with a lead researcher overseeing the process). To ensure inter-rater reliability researchers went through a joint period of 'learning'. In the initial development phase, samples of coded papers were swapped and re-coded by members of the research team to see if there was agreement. Any anomalies or inconsistencies were discussed and resolved by the research team.

2) After the development phases there was a test phase whereby the lead researcher randomly chose a sample of papers from each researcher and coded them independently.

3) The final data clean phase, to ensure consistency of data collection, required the lead author to double code all of 1113 articles.

The final stage of this systematic review is to report the findings and disseminate them in a way so as to add to practitioner and academics understanding of the topics or themes discussed (Tranfield et al., 2003). This is the focus on the next two sections of this article.

\section{Findings and discussion}

The reviewers have analysed Supply Chain Management: An International Journal and the Journal of Purchasing and Supply Management and Journal of Supply Chain Management and the Journal of Supply Chain Management. The findings and observations presented here come from a data set of 1113 articles, spanning the period 1994-2009. Although, as discussed, Fabian had three criteria that can be used to categorise an academic discipline, the key one is coherence. Therefore, the findings related to coherence feature heavily in the findings and discussion. Her second criteria, breadth and depth and third, quality are the factors that indicate if a discipline is ever likely to develop a clear paradigm. The second criteria relates to epistemological unity i.e. can researchers agree on what constitutes knowledge? The third criteria, quality, which is linked to the former criteria, is have the authors provided evidential support in order to have made a useful contribution to knowledge in this area; and if so, what form must this evidence take (case or statistical)?

The findings are organised into three sections to provide answers to the key research questions:

RQ1. To what extent is theory used in P\&SCM research?

RQ2. What are the prevalent theories to be found in P\&SCM research?

RQ3. To what extent does P\&SCM meet the tests of coherence, breadth and depth, and quality necessary to make it a scientific discipline? 
The headline features from the results suggest that in answer to RQ1 and RQ2, nearly a decade-and-a-half on from its development, the field still lacks coherence. There is the absence of theory in much of the work and there is no obvious contender as an emergent paradigm for the discipline. Furthermore, in answer to RQ3 it is evident that P\&SCM does not meet Fabain's test necessary to make it a scientific discipline and is still some way from being a normal science. This is because first, there continues to be over the research period, a significant number of articles having no distinctive intellectual tradition (NDIT), with an underlying trend of an increase in intellectually eclectic articles (see Table 5 and Figure 2). Second, the discipline lacks epistemological unity, with the majority of articles being inductive (evidence-led). Third, the findings show little evidence of establishing norms when it comes to the conducting of research (Table 6).

Table 5: The use of theory in the discipline

\begin{tabular}{|c|c|c|c|c|c|c|c|c|c|c|c|c|}
\hline & \multicolumn{3}{|c|}{$1996-1999$} & \multicolumn{3}{|c|}{$2000-2004$} & \multicolumn{3}{|c|}{$2005-2009$} & \multicolumn{3}{|c|}{ Total } \\
\hline & $\mathrm{N}$ & $\%$ & $\begin{array}{c}\%- \\
\text { NDIT }\end{array}$ & $\mathrm{N}$ & $\%$ & $\begin{array}{l}\%- \\
\text { NDIT }\end{array}$ & $\mathrm{N}$ & $\%$ & $\begin{array}{c}\%- \\
\text { NDIT }\end{array}$ & $\mathrm{N}$ & $\%$ & $\begin{array}{c}\%- \\
\text { NDIT }\end{array}$ \\
\hline $\begin{array}{l}\text { Integrated Supply Chain } \\
\text { Management (ISCM) }\end{array}$ & 86 & 26.0 & 68.3 & 64 & 17.9 & 44.4 & 54 & 12.7 & 36.0 & 204 & 18.3 & 48.6 \\
\hline $\begin{array}{l}\text { Transaction Cost Economics } \\
\text { (TCE)/Principal Agency } \\
\text { Theory (PAT) }\end{array}$ & 9 & 2.7 & 7.1 & 19 & 5.3 & 13.2 & 10 & 2.4 & 6.7 & 38 & 3.4 & 9.0 \\
\hline $\begin{array}{l}\text { Resource Dependency Theory } \\
\text { (RDT) }\end{array}$ & 10 & 3.0 & 7.9 & 16 & 4.5 & 11.1 & 12 & 2.8 & 8.0 & 38 & 3.4 & 9.0 \\
\hline $\begin{array}{l}\text { Industrial Marketing and } \\
\text { Purchasing(IMP) / Network } \\
\text { Theory(NT) }\end{array}$ & 3 & 0.9 & 2.4 & 8 & 2.2 & 5.6 & 9 & 2.1 & 6.0 & 20 & 1.8 & 4.8 \\
\hline $\begin{array}{l}\text { Resource Based View (RBV)/ } \\
\text { Dynamic Capabilities } \\
\text { Approach(DCA) }\end{array}$ & 1 & 0.3 & 0.8 & 4 & 1.1 & 2.7 & 7 & 1.7 & 4.6 & 12 & 1.1 & 2.9 \\
\hline Contingency Theory (CT) & 1 & 0.3 & 0.8 & 0 & 0.0 & 0.0 & 7 & 1.6 & 4.7 & 8 & 0.7 & 1.9 \\
\hline Industrial Organisation(IO) & 0 & 0.0 & 0.0 & 1 & 0.3 & 0.7 & 2 & 0.5 & 1.3 & 3 & 0.3 & 0.7 \\
\hline Other & 3 & 0.9 & 2.4 & 14 & 3.9 & 9.7 & 18 & 4.2 & 12.0 & 35 & 3.1 & 8.3 \\
\hline Sub-Total & (113) & (34.1) & $(89.7)$ & (126) & (35.2) & $(87.5)$ & (119) & (28.1) & (79.3) & (359) & (32.2) & $(85.2)$ \\
\hline Intellectually Eclectic(IE) & 13 & 3.9 & 10.3 & 18 & 5.0 & 12.5 & 31 & 7.3 & 20.7 & 62 & 5.5 & 14.8 \\
\hline $\begin{array}{l}\text { No Distinctive Intellectual } \\
\text { Tradition(NDIT) }\end{array}$ & 205 & 61.9 & - & 214 & 59.7 & - & 274 & 64.6 & - & 693 & 62.3 & - \\
\hline Total & 331 & 100.0 & 100.0 & 358 & 100.0 & 100.0 & 424 & 100.0 & 100.0 & 1113 & 100.0 & 100.0 \\
\hline
\end{tabular}


Figure 1: The use of theory in the discipline, 1994-2009

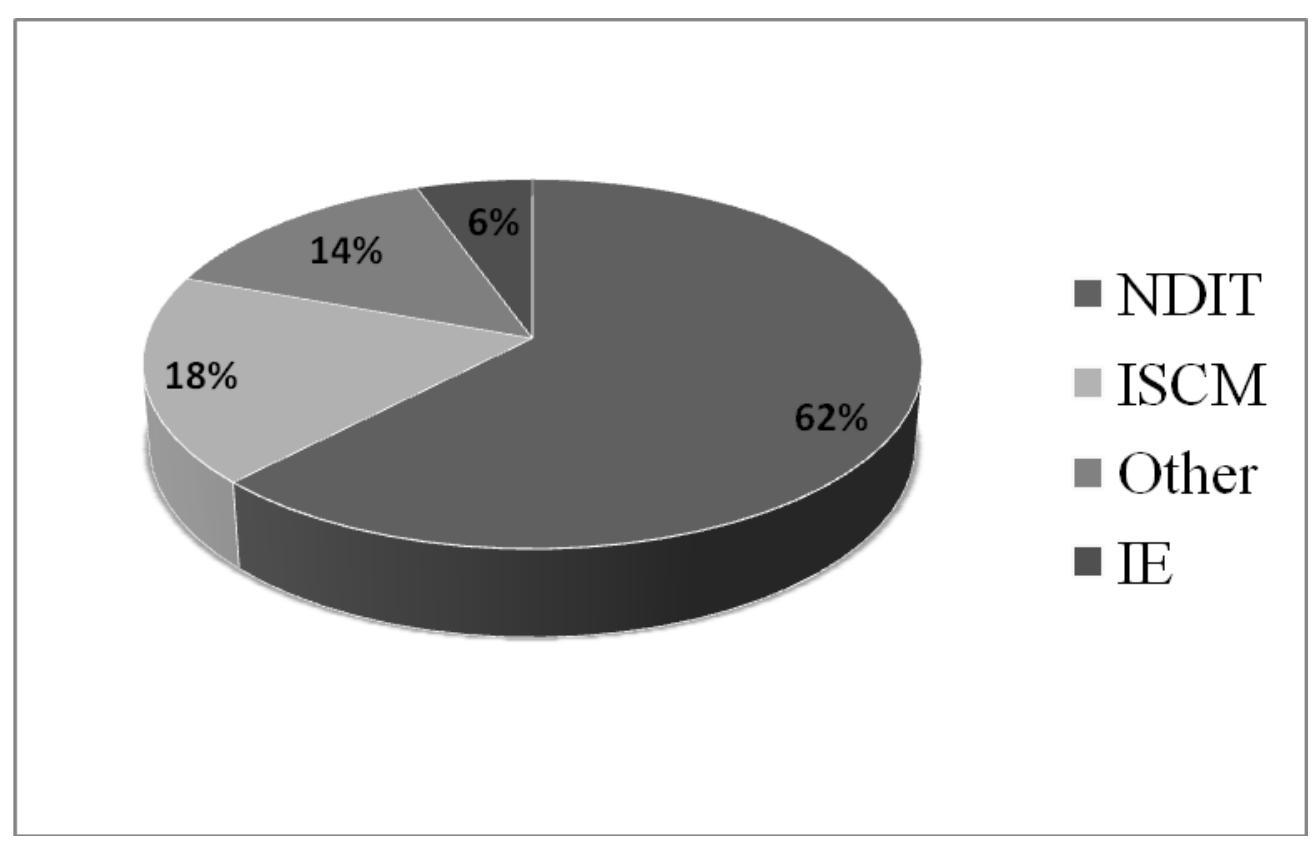

Figure 2: Trends in the use of theory in the discipline, 1994-2009

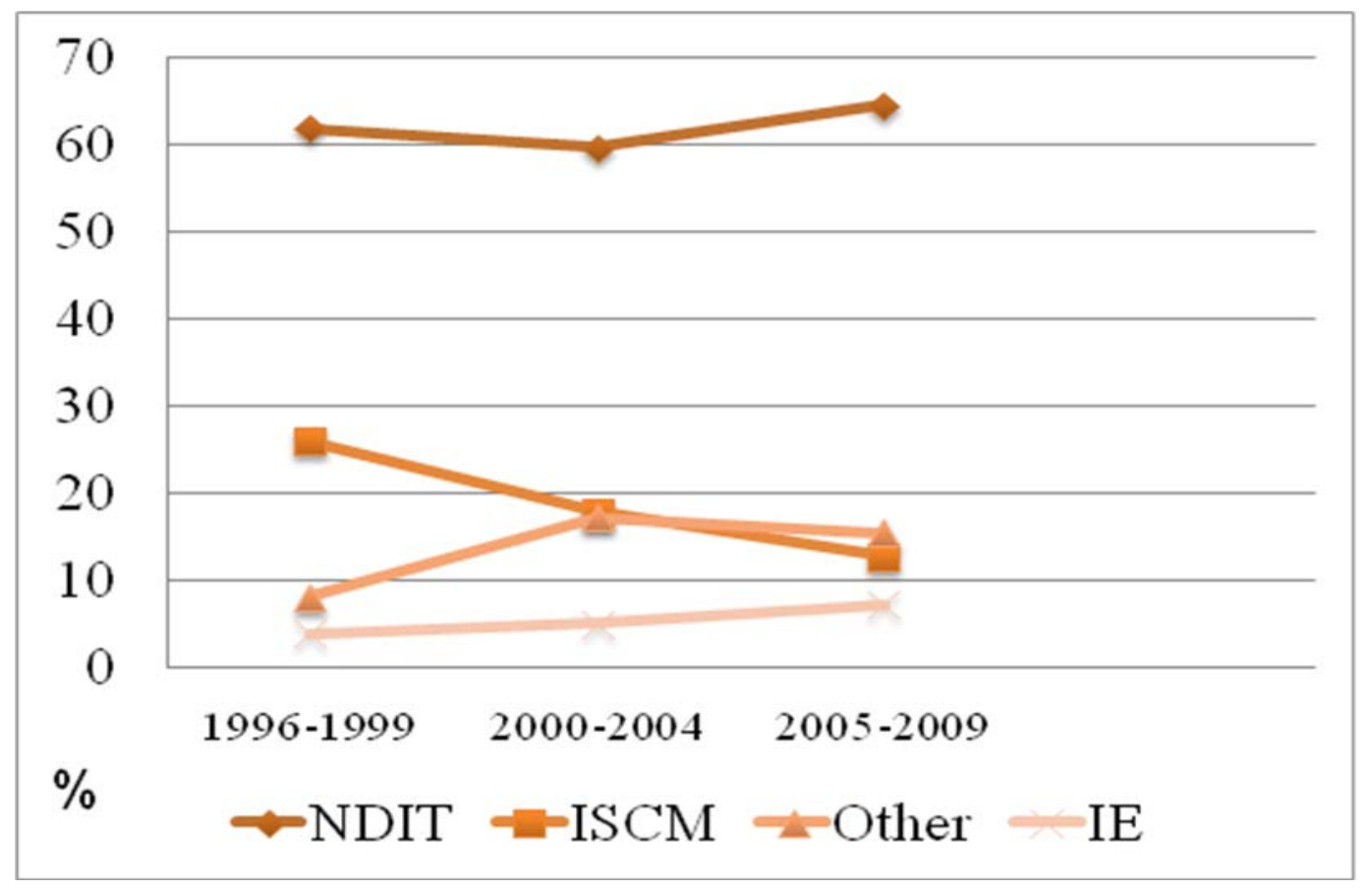

\section{RQ1. To what extent is theory used in P\&SCM research?}

First, it is clear that there was the absence of theory in much of the work. Second, and this was perhaps most startling, there was an increasing number of articles in the latter period 
having no distinctive intellectual tradition. In the period 1994-9 the figure for the No Distinctive Intellectual Tradition (NDIT) category was 61.9\%. For the period 2000-4 it was $59.7 \%$, while for the period $2005-9$ it climbed up to $64.6 \%$. Overall, only $37.7 \%$ of the articles could be associated with a tradition of any kind, with $62.3 \%$ of articles having NDIT (see Table 5 and Figure 1).

\section{RQ2. What are the prevalent theories to be found in P\&SCM research?}

Furthermore, even where a theoretical approach could be identified, there was no obvious candidate for an emerging paradigm. Although, over the sixteen year period, the ISCM family of approaches proved to be the most popular of the approaches (48.6\% of the articles where an approach could be identified), this was still only $18.3 \%$ of the articles overall (see Table 5 and Figure 1). Furthermore, contrary to the findings of Richey et al. (2010) who argue that ISCM is possibly emerging as central theory of P\&SCM, our research indicates that the relative popularity of the approach has been in decline over the sixteen year period. In the early days of the field it looked as if lean and agile supply techniques might provide the intellectual basis for the discipline. In the period 1994-9, where an approach could be identified, ISCM (which at that time meant lean) accounted for over two-thirds (68.3\%) of the published articles in the journal (26.0\% of the articles overall). However, since that time this figure has fallen away. In 2000-4 ISCM accounted for 44.4\% of the articles that exhibited an intellectual preference (17.9\% of the articles overall). By the third period (20059), this figure had fallen to $36.0 \%$ (12.7\% of all the articles overall) (see Table 5 and Figure 2). Conversely, whilst ISCM's popularity has declined there has been an increase in the use of other theories. Taking all identified theories and Intellectually Eclectic (IE) articles together, we see that where an approach could be identified this accounted for $24.4 \%$ in period 1 (1994-9) (12\% of articles overall), rising to 43.1\% in period 2 (2000-2004) (22.3\% of articles overall) and $43.3 \%$ in the third period (2005-2009) (22.6\% of articles overall). Such a finding is open to a number of interpretations. Either the evidence that has accumulated over the last sixteen years has discredited the approach, or a more efficient alternative has been discovered. A further explanation is that the limits to the perspective have been reached. While ISCM has proven well-suited to providing answers to certain types of problems, these problems have fallen within a fairly narrow range. As the agenda of the discipline has broadened, researchers have had to cast their nets more widely for explanations.

If this indeed is the case then it would appear that the discipline has yet to find a satisfactory alternative to ISCM. The next three most popular approaches taken together (TCE-PAT, RDT and IMP/NT) only account for only $8.6 \%$ of the articles in the journals (or $22.8 \%$ of the articles with a clear intellectual preference). In addition, there is no evidence that TCE-PAT, RDT or IMP/Network Theory are on a significant upward trajectory. Indeed, it would seem that for two of these approaches their influence has waned since a high in the period 2000-4, where TCE-PAT, accounted for $13.2 \%$ of articles with a clear intellectual preference (or $5.3 \%$ of all articles) and RDT accounted for $11.1 \%$ (4.5\% of all articles), falling to $6.7 \%$ (2.4\%), and 8.0\% (2.8\%). IMP/NT showed a modest rise from 5.6\%, in the period 2000-2004 
to $6.0 \%$. However as a percentage of all articles there was also a decline from $2.2 \%$ to $2.1 \%$ over the two periods. Furthermore, there was an increase in the use of 'other' theories (those articles not categorised as TCE-PAT, IO, RDT, RBV, IMP/NT or Contingency Theory), which accounted for $2.4 \%$ of the articles with a clear intellectual perspective in the period 1994-9, 9.7\% in the period 2000-4, growing to 12.0\% in the period 2005-9. There have been recent attempts to ground P\&SCM in a number of 'other' theories including social network theory (Borgatti, 2009), Resource-Advantage theory (Hunt and Davis, 2008), in servicedomiant logic (Randall et al., 2010) and Marketing's functionalist theory (Svensson, 2002), to name but a few. The relative decline of ISCM has given way to a disciplinary pluralism; it has not given rise to an intellectual challenger.

Even more worrying is the intellectual promiscuity exhibited by an increasing number of researchers in the field. That is to say, there has been a rise in the number of articles that seek to marry not just distinct but also intellectually incommensurable traditions. Amundson (1998) discusses importing alien theories from other disciplines to help shed light on operations management and other disciplines. She suggests that the imported theories need to suit the investigation of similar phenomena, be commensurable with the concepts under investigation, and need to share similar underlying assumptions. For example, if one were focusing on studying the behaviour of purchasing managers in buyer-supplier relationships, it might be more suitable to look to behavioural theories from sociology or psychology, rather than adopting a TCE perspective that draws on an economics tradition. Another example might relate to the unit of analysis; an investigation of supply networks would more usefully draw on network theory than on the resource based view of the firm, which takes the firm rather than the network as the unit of analysis. In the period 1994-9, 10.3\% of the articles where there was a distinct theoretical approach sought to marry theories from different traditions (3.9\% for all articles). By 2000-4 this figure had risen to $12.5 \%$ (5.0\%) and by 2005-9 to 20.7\% (7.3\%) (see Table 5 and Figure 2). Typical of this intellectual eclecticism are a number of articles that attempted to fuse the RBV-DCA from mainstream business strategy, and TCE-PAT from mainstream and new institutional economics. The issue of ontological commensurability must clearly be of some concern - not least because it is likely to hamper P\&SCM's progress towards a normal science state.

\section{RQ3. To what extent does P\&SCM meet the tests of coherence, breadth and depth, and quality necessary to make it a scientific discipline?}

Taking the key issue of coherence first, there are a number of notable observations. From the results it is clear that in its early days, P\&SCM was a relatively inward-looking discipline. The example of ISCM is a case in point. ISCM was developed by P\&SCM specialists on the basis of their observations about Japanese manufacturing practice. Furthermore, the lack of theory in P\&SCM could be because the discipline is very applied and it may also be difficult to obtain empirical data. The RBV-DCA, TCE-PAT, IO and IMP/NT played little part in the early development of the subject. This is despite the fact that all of these approaches were around in the early 1990s. For example, the study of IO is as old as the discipline of 
economics itself. Adam Smith's work makes repeated reference to the operation of competitive markets. TCE has its roots in the 1930s. It emerged as a coherent approach in the 1970s and it took off in the 1980s. However, neither tradition was much discussed in the early writings on P\&SCM. More recently, with the possible exception of IO, all of these approaches have started to make their presence felt. However, just how important they are likely to be is hard to say. A number of them have the potential to be quite influential. The RBV-DCA, for example, talks directly to the subject of competitive strategy and has a number of useful things to say about the value-adding nature of relationships. TCE also has an interest in relationships; while PAT holds the prospect of deepening our understanding of contracts. However, while it is likely that all of these approaches will increase their influence on the discipline in future years, it is unlikely that any of them will provide the basis for the development of a disciplinary paradigm. The research agenda of P\&SCM is simply too broad for RBV-DCA to be a viable candidate. And, while between the two of them, TCEPAT might offer the range of insight that would be required for the development of a paradigm, they are unlikely to attract sufficient disciples necessary to fulfil the role. Is this because the behavioural assumptions that underpin both TCE and PAT sit uncomfortably with most of the researchers currently writing on P\&SCM?

In relation to Fabian's second criteria, breadth and depth, it was evident from the research that a significant proportion of the articles were inductive (evidence-led) (66.3\%), rather than being deductive (theory-led) (26.6\%) or hypothetico-deductive (self-consciously attempts to test evidence against theory) (7.1\%) (see Table 6 below). Each of these epistemological approaches is equally valuable, however we can conclude (based upon Fabian's criteria) that the discipline lacks the necessary reflection to progress to a natural science. However, it should also be noted that there is a strong positivist tradition (rather than constructionist) in this discipline. Positivism more readily lends itself to the progression of unified knowledge and the establishment of a dominant paradigm (Gallie, 1955-6). 
Table 6: Epistemological approach in the discipline

\begin{tabular}{|l|c|c|c|c|c|c|c|c|}
\hline & \multicolumn{2}{|c|}{ Inductive } & \multicolumn{2}{c|}{ Deductive } & $\begin{array}{c}\text { Hypothetico - } \\
\text { Deductive }\end{array}$ & \multicolumn{2}{c|}{ Total } \\
\cline { 2 - 10 } & $\mathrm{N}$ & $\%$ & $\mathrm{~N}$ & $\%$ & $\mathrm{~N}$ & $\%$ & $\mathrm{~N}$ & $\%$ \\
\hline Conceptual & - & - & 141 & 12.7 & - & - & 141 & 12.7 \\
\hline Literature Review & - & - & 27 & 2.4 & - & - & 27 & 2.4 \\
\hline Simulation & - & - & 37 & 3.3 & - & - & 37 & 3.3 \\
\hline Statistical Survey & 349 & 31.4 & - & - & 55 & 4.9 & 404 & 36.3 \\
\hline Technical & - & - & 31 & 2.8 & - & - & 31 & 2.8 \\
\hline Case-based & 360 & 32.4 & - & - & 25 & 2.2 & 385 & 34.6 \\
\hline Positional & - & - & 60 & 5.4 & - & - & 60 & 5.4 \\
\hline Other & 28 & 2.5 & - & - & - & - & 28 & 1.7 \\
\hline Total & 737 & 66.3 & 296 & 26.6 & 80 & 7.1 & 1113 & 100.0 \\
\hline
\end{tabular}

Finally, there is the issue of methodological norms within the discipline - or rather the lack of them (Fabian's third criteria of quality). Many researchers writing in the area eschew the use of grand theory. They prefer instead to use case material as the basis upon which to draw their lessons. 34.6\% of all the articles published relied on case material (see Table 7 and Figure 3 below). We have already seen that well over half of the articles published in this period made no use of theory. Other writers, by contrast, sit at the opposite end of the spectrum, preferring instead to derive their insights from deductive reflection. Perhaps not surprisingly, conceptual pieces accounted for a greater proportion of the published work in the early part of the period surveyed (14.5\%). In recent years this number has declined. In the last period surveyed, conceptual articles accounted for $12.3 \%$ of the articles published in the journal (see Table 7 and Figure 3 below). Finally, there are a significant number of authors who prefer the type of scientific formalism typically found in the natural sciences. In our survey we found that $42.2 \%$ of researchers preferred these sorts of strategy (simulation, statistical survey and technical-see Table 7). It is interesting to note that over the three periods studied the popularity of statistical survey over case-based research seems to have converged, with both approaches being of almost equal importance in the final period (see Figure 4 below). Of course, the existence of this methodological pluralism does not imply that the research being done is of poor quality. However, if there is not a clear agreement on how to conduct research (breadth and depth) as well as the absence of clear research norms (quality) this will make it more difficult for P\&SCM to make progress towards becoming a normal science, in the Kuhnian sense. 
Table 7: Research strategy in the discipline

\begin{tabular}{|l|c|c|c|c|c|c|c|c|}
\hline & \multicolumn{2}{|c|}{$1996-1999$} & $2000-2004$ & $2005-2009$ & \multicolumn{2}{c|}{ Total } \\
\cline { 2 - 9 } & $\mathrm{N}$ & $\%$ & $\mathrm{~N}$ & $\%$ & $\mathrm{~N}$ & $\%$ & $\mathrm{~N}$ & $\%$ \\
\hline Conceptual & 48 & 14.5 & 41 & 11.5 & 52 & 12.3 & 141 & 12.7 \\
\hline Literature Review & 4 & 1.2 & 9 & 2.5 & 14 & 3.3 & 27 & 2.4 \\
\hline Simulation & 9 & 2.7 & 13 & 3.6 & 15 & 3.5 & 37 & 3.3 \\
\hline Statistical Survey & 126 & 38.1 & 125 & 34.9 & 153 & 36.1 & 404 & 36.3 \\
\hline Technical & 6 & 1.8 & 14 & 3.9 & 11 & 2.6 & 31 & 2.8 \\
\hline Case-based & 100 & 30.2 & 138 & 38.5 & 147 & 34.7 & 385 & 34.6 \\
\hline Positional & 27 & 8.2 & 16 & 4.5 & 17 & 4.0 & 60 & 5.4 \\
\hline Other & 11 & 3.3 & 2 & 0.6 & 15 & 3.5 & 28 & 2.5 \\
\hline Total & 331 & 100.0 & 358 & 100.0 & 424 & 100.0 & 1113 & 100.0 \\
\hline
\end{tabular}

Figure 3: Research strategy in the discipline, 1994-2009

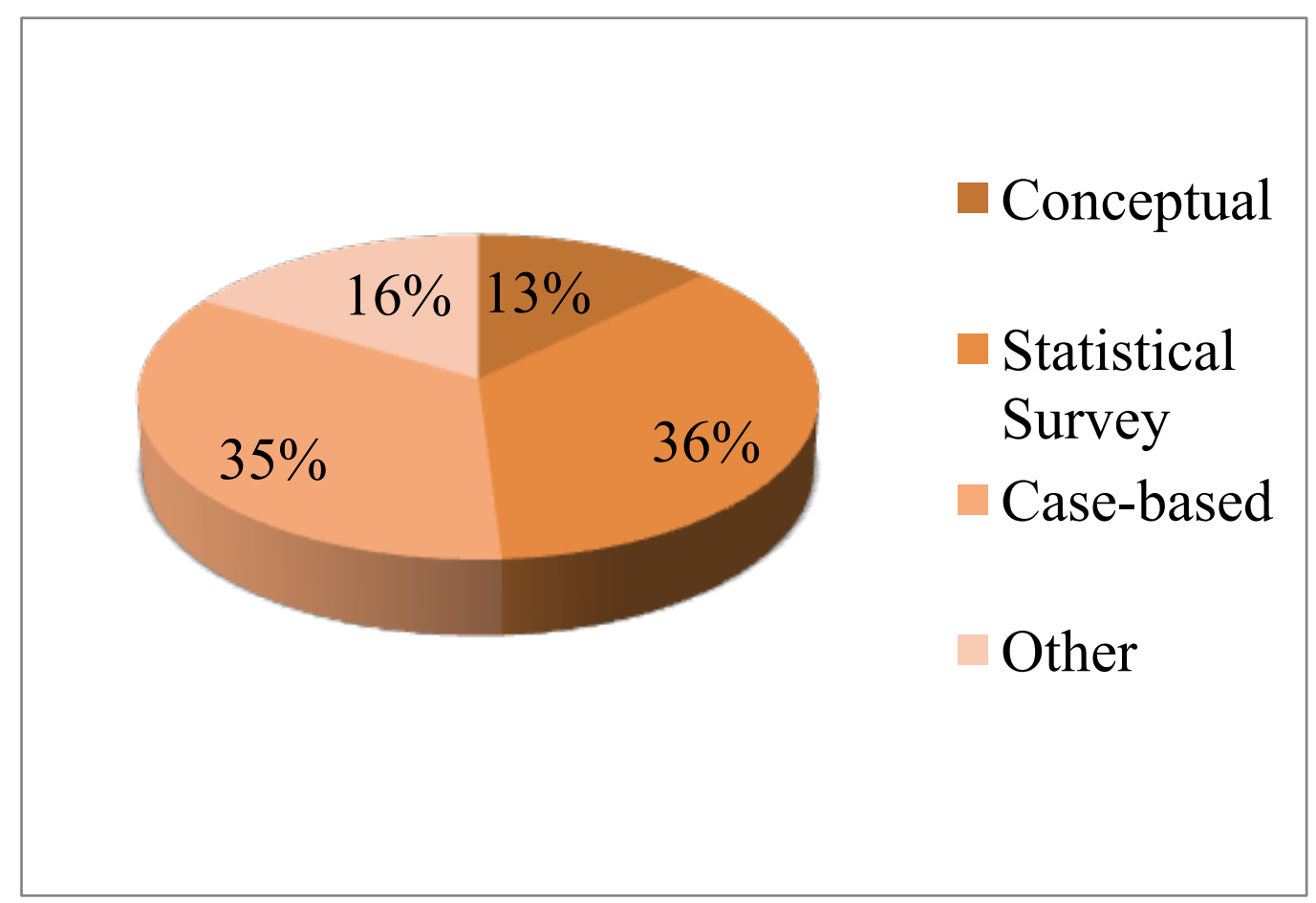


Figure 4: Trends in research strategy in the discipline, 1994-2009

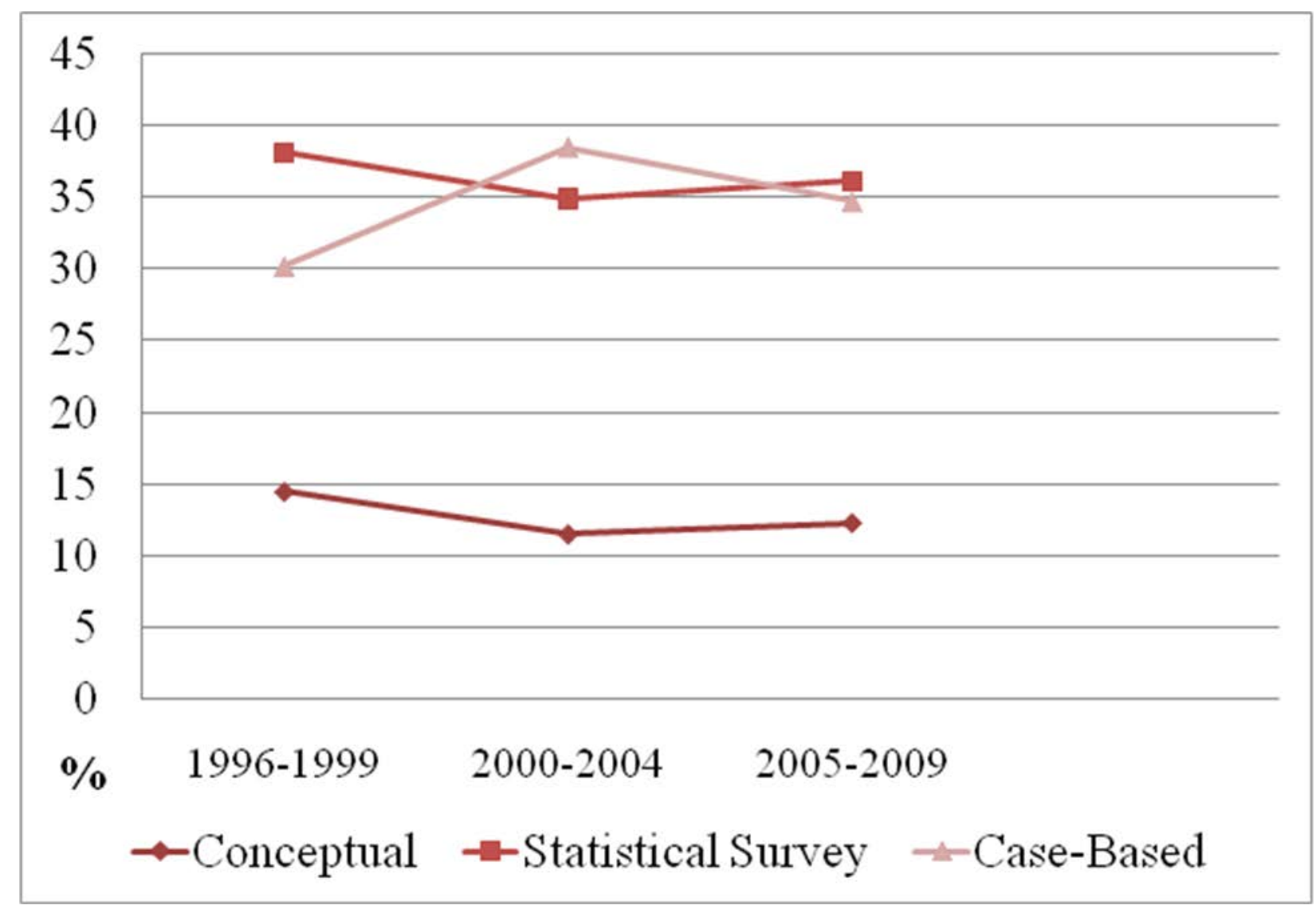

\section{Conclusions}

The research aim was to investigate to what extent P\&SCM can be said to be ready or indeed able to join the select group of modern scientific disciplines by answering three questions:

RQ1. To what extent is theory used in P\&SCM research?

RQ2. What are the prevalent theories to be found in P\&SCM research?

RQ3. To what extent does P\&SCM meet the tests of coherence, breadth and depth, and quality necessary to make it a scientific discipline?

To achieve the research aim this study has built on the existing literature. The work of Defee et al. (2010), has been extended by looking at the use of theory in the field of P\&SCM, rather than focusing more upon logistics. Furthermore, this study has built upon and updated the work of Harland et al. (2006). Finally, this study has increased the breadth of research by presenting results from the analysis of 1113 articles surveyed from three of the key journals in the P\&SCM field over a thirteen year period.

In addressing Fabian's first, and most important criterion, coherence, the research presented in this paper aimed to determine if: (a) the discipline has developed a robust and rich 
theoretical base; and (b) to the extent that such a base exists, are their signs of growing agreement amongst researchers about which are the most useful perspectives. From the research findings it is clear that there was an absence of theory in much of the work. Furthermore, there was little evidence that a single dominant paradigm has started to emerge. On the contrary, there was an increase in the last period (2005-2009), a period not covered in the earlier Harland et al. (2006) study, of articles increasingly having no distinctive intellectual tradition. Also, there was an increasing number of researchers in the field seeking to marry not just distinct but also intellectually incommensurable traditions. This issue of ontological commensurability is of some concern - not least because it is likely to hamper the disciplines progression towards a normal science state (Amundson, 1998). In conclusion, the evidence would suggest that P\&SCM is still in its infancy and is currently a segregated discipline.

This then raises the question of whether or not the discipline is likely to integrate at some future point. As has been previously argued in this paper the answer to this question rests on Fabian's second (breadth and depth) and third (quality) criteria. In relation to Fabian's second criteria, breadth and depth, it was evident from the research that a significant proportion of the articles were inductive, rather than being deductive or hypotheticodeductive. $6.6 \%$ of the articles reviewed relied upon hypothetico-deductive reasoning, often taken to be the gold standard of disciplinary enquiry. Although it was argued that each of the epistemological approaches is equally valuable, we can conclude that the discipline lacks the necessary reflection to progress to a natural science. Finally, there is the issue of methodological norms within the discipline (quality). The findings demonstrate that many researchers writing in the area eschew the use of grand theory, preferring instead to use case material as the basis upon which to draw their lessons (41\% of all the articles relied upon case-based research). We do not wish to imply that the existence of methodological pluralism means that research in this field is of poor quality. However, if there is not a clear agreement on how to conduct research (breadth and depth) as well as the absence of clear research norms (quality) this will make it more difficult for P\&SCM to make progress towards becoming a normal science, in the Kuhnian sense.

In conclusion, using Fabian's (2000) criteria, P\&SCM has some way to go as an academic field to be viewed as a discipline. In addition, as the discipline lends itself to such a broad range of agendas, for example, the internal politics of organisations or the role of contracts, it can be argued that it is unlikely that just one disciplinary paradigm will ever become dominant. The findings indicate that rather than a move towards a single dominant paradigm there is an increasingly eclectic approach to the use of theory in this discipline. We broadly agree with Harland et al.'s characterisation of the state of the literature, however we do not necessarily agree with their conclusions. P\&SCM is a discipline; it is just not a scientific discipline of the type described in the developmental framework of Harland et al.

There is the opportunity to conduct considerable further research by analysing other relevant academic journals in the field of P\&SCM. Additional research will aim to further progress and validate the current line of enquiry. There may also be scope to cross-analyse the 
selected journals to explore any differences that may arise (i.e. ontological and epistemological preferences). There is also a great deal of further analysis which can be conducted with the current data set. This may include identifying the key topics (i.e. JIT, TQM, and Partnering), the location (country) and sectoral focus of empirical studies and highlight any interesting trends.

\section{References}

Alchian, A. and Woodward, S. (1988), "The Firm is Dead: Long Live the Firm - A Review of Oliver Williamson's The Economic Institutions of Capitalism”, Journal of Economic Literature, Vol. 26 No 1, pp. 65-79.

Amundsen, S.D. (1998), "Relationships between theory-driven empirical research in operations and other disciplines”, Journal of Operations Management, Vol. 16, pp. 341-49.

Barney, J. (1991), "Firm Resources and Sustained Competitive Advantage”, Journal of Management, Vol. 17 No. 1, pp. 99-120.

Burgess, K., Singh, P. and Koroglu, R. (2006), "Supply Chain Management: A Structured Literature Review and Implications for Future Research”, International Journal of Operations and Production Management, Vol. 26 No. 7, pp.703-29.

Coase, R.H. (1937), 'The Nature of the Firm', Economica, Vol. 4, pp. 386-405.

Conner, K. and Prahalad, C. (1996), 'A Resource-based Theory of the Firm: Knowledge Versus Opportunism’, Organization Science, Vol. 7 No. 5, pp. 477-501.

Connolly, W.E. (1972), “On 'Interests’ in Politics”, Politics Society, Vol 2. (Summer), pp.459-477. Cox, A., (1997), Business Success, Boston, Earlsgate Press.

Cox, A., Sanderson, J. and Watson, G. (2000), Power Regimes: Mapping the DNA of Business and Supply Chain Relationships, Earlsgate Press, Stratford-upon-Avon.

Cusumano, M. (1984), The Japanese Automotive Industry, Harvard University press, Cambridge, MA.

Defee C.C., Williams, B., Randall, W.S. and Thomasd, R. (2010), “An inventory of theory in logistics and SCM research”, International Journal of Logistics Management, Vol. 21 No 3, pp. 404-489.

Demsetz, H. (1973), “Industry Structure, Market Rivalry and Public Policy”, Journal of Law and Economics, Vol. 16 No.1.

Denyer, D., and Tranfield, D. (2009), Producing a systematic review, In D. A. Buchanan and A. Bryman (Eds.), The SAGE handbook of organizational research methods (pp. 671-689), London: SAGE Publications Ltd.

Eggertsson, T. (1996), “A Note on Economic Institutions”, in L. Alston, T. Eggertsson and D. North (Eds.), Empirical Studies in Institutional Change, pp.342-355 (HB99.5).

Ellram, L.M. (1990), “Supplier Selection Decisions in Strategic Partnerships”, Journal of Purchasing and Materials Management, Vol. 26 No. 4, pp. 8-14.

Emerson, R. (1962), “Power-Dependence Relations”, American Sociological Review, Vol. 27, pp.3141.

Fabian, F. (2000), "Keeping the Tension: Pressures to Keep the Controversy in the Management Discipline”, Academy of Management Review, Vol. 25 No. 2, pp. 350-72.

Feyerabend, P. (1975), Against Method, Thetford, Lowe and Brydone.

Ford, D. (1980), “The Development of Buyer-Seller Relationships in Industrial Markets”, European Journal of Marketing, Vol. 14 No. 5/6, pp. 339-353.

Foss, N. (2005), Strategy, Economic Organization and the Knowledge Economy. Oxford, Oxford 
University Press, pp.61-78.

Gallie, W.B. (1955-56), "Essentially Contested Concepts”, Proceedings of the Aristotelian Society New Series, Vol. 56, pp. 167-198.

Giunipero, L.C, Hooker, R.E., Joseph-Matthews, S., Yoon, T.E. and Brudvig, S. (2008), “A decade of SCM literature: past, present and future implication”, Journal of supply Chain Management: A Global Review of Purchasing and Supply, Vol. 44 No 4, pp. 66-86.

Halldorsson, A., Kotzab, H., Mikkola, J. and Skjøtt-Larson, T. (2007), “Complementary Theories to Supply Chain Management”, Supply Chain Management: An International Journal, Vol. 12 No. 4, pp. 284-96.

Harland, C., Lamming, R., Walker, H., Philips, W., Caldwell, N., Johnsen, T., Knight, L. and Zheng, J. (2006), "Supply Management: Is it a Discipline?”, International Journal of Operations and Production Management, Vol. 26 No. 7, pp. 730-53.

Hart, O. (1989), “An Economist's Perspective on the theory of the Firm”, Columbia Law Review, Vol. 89 No. 7, pp. 1757-74.

Harvey, C., Morris, H. and Kelly, A. (2009), Academic Journal Quality Guide, University of West England, Bristol: The Association of Business Schools.

Hollis, M. (1997), Invitation to Philosophy, $2^{\text {nd }}$ Edition, Oxford, Blackwell Publishers.

Hunt. S.D. (1991), Modern Marketing Theory: Critical Issues in Philosophy of Marketing Science, South-Western, Cincinnati, $\mathrm{OH}$.

Klein, K.J., Dansereau, F. and Hall, R.J. (1994), ”Levels issues in theory development, data collection and analysis”, Academy of Management Review, Vol. 19, pp. 195-229.

Kuhn, T.S. (1970), The Structure of Scientific Revolutions, Chicago, University of Chicago Press.

Lamming, R. (1993), Beyond Partnership: Strategies for Innovation and Lean Supply, Hemel Hempstead, Prentice Hall.

Lamming, R (1996), “Squaring lean supply with supply chain management”, International Journal of Operations \& Production Management, Vol. 16 No. 2, pp. 183-96.

Lukes, S. (1974), Power: A radical View, Macmillan, Harmondsworth.

Lukes, S. (ed) (1986) Power: Readings in Social and Political Theory, Oxford: Basil Blackwell.

Macbeth, D. and Ferguson, N. (1994), Partnership Sourcing: An Integrated Supply Chain Approach, Pitman, London.

March, J. (1996), "Continuity and Change in theories of organizational action”, Administrative Science Quarterly, Vol. 41, pp. 278-287.

March, J. and Simon, H. (1958), Organizations, New York and London, John Wiley \& Sons.

McLennan, G. (1989) Marxism, Pluralism and Beyond: Classic Debates and New Departures, Cambridge: Polity Press.

Milgrom, P. and Roberts, J. (1992), Economics, Organization and Management, Englewood Cliffs, NJ, Prentice Hall, pp.125-247 (HF5500).

Miri-Lavassani, K., Movahedi, B. and Kumar V. (2009), "Developments in theories of supply chain management: the case of B2B electronic marketplace adoption”, International Journal of Knowledge,Culture and Change Management, Vol. 9 No. 6, pp. 85-98.

Miyazaki, A.d., Phillips, J.K. and Phillips, D.M. (1999), “Twenty years of JBL: an analysis of published research”, Journal of Business Logistics, Vol. 20 No.2, pp. 1-20.

Pfeffer, J. (1982), Organizations and organization theory, Marshfield, MA: Pitman.

Pfeffer, J. (1993), "Barriers to the Advance of organizational Science: Paradigm Development as a Dependent Variable”, Academy of Management Review, Vol. 188, pp. 599-620.

Porter, M. (1979), “How Competitive Forces Shape Strategy”, Harvard Business Review, MarchApril, pp. 137-156.

Porter, M. (1981), "The Contributions of Industrial Organization to Strategic Management”, Academy of Management Review, Vol. 6 No. 4, pp. 609-20. 
Porter, M. (1991), “Towards a Dynamic Theory of Strategy”, Strategic Management Journal, Vol. 12 (Special Issue), pp. 95-117.

Ramsay, J. (1996), “The Case Against Purchasing Partnerships”, International Journal of Purchasing and Materials Management, Vol. 32 No. 4, pp. 13-19.

Ramsay, J. (2004), "Serendipity and the realpolitik of negotiations in supply chains”, Supply Chain Management: An International Journal, Vol. 9 No. 3, pp. 219-229.

Richey, R.G., Roath, A.S., Whipple, J.M. and Fawcett, S.E. (2010), "Exploring a Governance

Theory of Supply Chain Management: Barriers and Facilitators to Integration,” Journal of Business Logistics, Vol. 31 No 1, pp. 237-256.

Rousseau, D.M., Manning, J. and Denyer D. (2008), “Evidence in management and organizational science: assembling the fields full weight of scientific knowledge through synthesis", Academy of Management Annals, Vol. 2, pp. 475-515.

Rumelt, R., Schendel, D. and Teece, D. (1991), “Strategic Management and Economics”, Strategic Management Journal, Vol. 12, pp. 5-29.

Salancik, G. and Pfeffer, J. (1977), "Who Gets Power - And How They Hold on to It: A Strategic Contingency Model of Power”, Organizational Dynamics, Vol. 6, pp. 3-21.

Saunders, M., Lewis, P. and Thornhill, A. (2007), Research Methods for Business- Fourth Edition, Pearson Education Limited Harlow.

Selviaridis, K. And Spring, M. (2007), “Third party logistics: a literature review and research agenda”, International Journal of Logistics Management, Vol. 18 No. 1, pp. 125-50.

Shook, C.L., Adams, G.L., Ketchen Jr, D.J. and Craighead, C.W. (2009), “Towards a "theoretical toolbox” for strategic sourcing”, Supply Chain Management: An International Journal, Vol. 14 No. 1, pp. 3-10.

Stock, J.R. (1994), “Applying theories from other disciplines to logistics”, International Journal of Physical Distribution \& Logistics Management, Vol. 27 No. 9/10, pp. 515-39.

Stock, J.R. (2001), “Doctoral research in logistics and logistics-related areas: 1992-1998”, Journal of Business Logistics, Vol. 22 No 1, pp. 125-256.

Stock, JR. and Broadus, C.J. (2006), "Doctoral research in supply chain management and/or logisticsrelated areas: 1999-2004”, Journal of Business Logistics, Vol. 27 No.1, pp. 139-51.

Stock, J.R. and Luhrsen, D.A. (1993), “Doctoral research in logistics-related areas: 1987-1991”, Journal of Business Logistics, Vol. 14 No2, pp. 197-373.

Stoker, G. (1995), 'Introduction' in D. Marsh and G. Stoker (eds.) Theory and methods in the Political Science, Macmillan, London.

Teece, D., Pisano, G. and Shuen, A. (1997), “Dynamic Capabilities and Strategic Management”, Strategic Management Journal, Vol. 18 No. 7, pp. 509-33.

Thorelli, H.B. (1986), “Networks: between markets and hierarchies”, Strategic Management Journal, Vol. 7, pp. 37-51.

Tranfield, D., Denyer, D. and Smart P. (2003), “Towards a Methodology for Developing EvidenceInformed Management Knowledge by Means of Systematic Review”, British Journal of Management, Vol. 14, pp. 207-222.

Tsoukas, H. (1994), "Refining common sense: Types of knowledge in management studies”, Journal of Management studies, Vol. 31, pp. 761-780.

Wacker, J.G. (1998), “A definition of theory: research guidelines for different theory-building research methods in operations management”, Journal of Operations Management, Vol. 16, pp. 361-385.

Williams, B.D. and Toker, T. (2008), “A review of inventory management research in major logistics 
journals themes and future directions”, International Journal of Logistics Management, Vol. 19 No. 2, pp.212-32.

Williamson, O. (1985), The Economic Institutions of Capitalism, Free Press, New York.

Williamson, O. (1991), "Comparative Economic Organization: The Analysis of Discrete Structural Alternatives”, Administrative Science Quarterly, Vol. 36, pp. 269-96.

Williamson, O. (1995), "Hierarchies, Markets and Power in the Economy: An Economic Perspective”, Industrial and Corporate Change, Vol. 4 No. 1, pp. 21-49.

Williamson, O. (2000), “New Institutional Economics: Taking Stock, Looking Ahead”, Journal of Economic Literature, Vol. 38 No.3, pp. 595-613.

Womack, J., Jones, D. And Roos, D. (1990), The Machine that Changed the World, Macmillan Publishing Company, New York, NY.

Womack, J. and Jones, D. (1996), Lean Thinking: Banish Waste and Create Wealth in Your Corporations, Simon and Schuster, New York. 